\title{
Cellular and molecular-genetic mechanisms of symbiosis and associative interaction of microorganisms with plants in rhizosphere
}

\author{
L. G. Lioshina
}

Institute of Bioorganic Chemistry and Petrochemistry, NAS of Ukraine

1 Murmanska Str., Kyiv 02094 Ukraine

llioshina@ukr.net

\begin{abstract}
The review contains the results of research on symbiotic and associative interaction of microorganisms and plants in rhizosphere. A special attention is given to the process of contact association of microorganisms and plants tissues including the concrete molecular structures and dominant role pertaining to protein-carbohydrate interaction. There are common features and distinctions at formation of arbuscular mycorhiza, rhizobia-legume symbiosis and association of non-leguminous plants with Azospirillum .
\end{abstract}

Key words: symbiosis, associative interaction, arbuscular mycorhiza, rhizobia, Azospirillum.

The current data prove total dependence of vital functions of plants on micro organisms in natural conditions [1]. Molecular-genetic methods revealed considerable variety of microflora for definite plants [2,3]. Photosynthesis in higher plants provides them with energy and carbon, while plants may obtain other necessary macro- and microelements (nitrogen and phosphor, in the first place) through the interaction with microorganisms in rhizosphere and rhizoplane. For instance, bacteria of genuses Azospirillum, Azotobacter, Arthrobacter, Bacillus, Clostridium, Enterobacter, Gluconoacetobacter, Pseudomonas, Rhizobium, Bradyrhizobium, Mesorhizobium, Sinorhizobium and Serratia provide plants with nitrogen, and mycorrhizal fungi ensure assimilation of phosphor, nitrogen, as well as a number of other microelements from soil. Besides, plants obtain phytohormones from exo- and endosymbionts, while toxins, synthesized by microorganisms, protect them from pathogenes and phytophages. Symbionts are also responsible for im-

Institute of molecular biology and genetics NAS of Ukraine, 2009 proving aqueous and mineral status of plants and decreasing ethylene amount [4-7].

Micorrhiza - a symbiotic association between Glomeromycota fungi and the roots of a plant - is the most typical symbiosis of plants and microbes (up to $90 \%$ of plant species). This association is known in two main variants: simple ectomycorrhiza (fungus does not penetrate into the plant cells), and endomycorrhiza, also called arbuscular mycorrhiza (AM), when hyphae of fungus enter the cells of plant roots. There are also symbiotic relations with nitrogen-fixing bacteria, which rhizobia and actinobacteria belong to. Some flowering plants are capable of cultivating these microorganisms in tubercles inside their root cells. Two possible kinds of such association are as follows: rhizobia-legume symbiosis (RLS) (with bacteria of Alphaproteobacteria group) $[8,9]$ and actinorhiza i.e. symbiosis with actinobacteria of Frankia genus. Actinobacteria form mycelial structures similar to fungal mycelia; therefore, they were originally classified as Actinomycetes [10]. 
Symbiotic associations between microorganisms and plant roots. Arbuscular mycorrhiza (AM). AM is the first and the oldest representative of symbiotic association between plant roots and microorganisms. It appeared about 450 million years ago. Fungal mycelium is located in intercellular space of the roots; it creates arbuscules (special trophic organs) which gave the name to this kind of micorrhiza. This type of symbiosis is usually obligate. Without association with plants mycorrhiza fungi may exist in the form of spores only; their sexual reproduction is yet uncertain; individual spores may contain hundreds of genetically different nuclei in the same cell $[11,12]$. This association between microscopic fungi and roots is especially valuable for those trees, bushes, and plants which have poor root system [13].

Alike other known associations between bacteria and plants, there are three stages of AM formation, namely, chemotaxis, attaching mycelium to the root, and colonization of surface or internal tissues of plant organs $[14,15]$.

AM development starts with preinfection and formation of appressorium with simultaneous germination of fungal spores, induced by root exudates. Primary hyphae grow, ramify, and create attachment structures i.e. appressoria. Later intercellular mycelium intergrows and infecting hyphae start emerging from appressoria. Via rhizodermis they penetrate cortex, where they colonize a cell, creating arbusculas, which, in turn, form branched structures, penetrating deeply into plant cells.

Arbusculas are located inside the plant (periarbuscular) membrane and reduced cell wall; they form dense knots with occasional emergences inside cells. They also ensure active exchange of metabolites between symbionts. While they are being formed, a matrix is created between walls of plant cells and hyphae; it contains polysaccharides and enzymes, synthesized by both partners. A number of cytological changes take place in a plant cell, namely, nucleus is increased and deformed; chromatine transfers to diffuse state; cytoplasm is characterized by increased amount of Golgi bodies and endoplasmic reticulum, taking part in the formation of periarbuscular membrane; vacuole is considerably decreased or vanishes completely; plastids transform into proplastids and the amount of tubulin increases. Off-root hyphae, ensuring adsorption of nutritious substances from soil, continue their development; asexual spores for fungus reproduction are formed $[16,17]$.

In root tubercles nutritious substances pass via perisymbiotic membrane, surrounding nitrogen-fixing bacteroides [18], while, in case of AM, exchange of dissolved substances takes place in perisymbiotic membranes, surrounding arbusculas [19]. There are evidences to similarity between epidermal penetration in case of AM and cortical preinfectious threads, formed during nodulation [20]; partial concurrent activation of gene expression was also proven [21]. The above mentioned similarity is specifically evident regarding cascades of acceptance and transfer of signals, initiating nodulation and mycorrhization [22]. The latest elaborations in this field have been analyzed in reviews [23-25].

Genes, participating in both association types, were called common symbiosis genes [26]. Analysis of proteins, encoded by these genes, revealed the majority of them to have conservative structure, present in all the flowering plants. SYMRK (symbiosis receptor kinase) was the only registered variable exception. It is a trans-membrane protein, the extracellular part of which is of different length. "Long variant" is common for nodulating plants, and their closest relatives; "middle variant" is registered for the farthest dicotyledonous relatives of nodulating plants; "short variant" is distinctive for monocotyledonous plants (rice and corn). Tubercles of any type (both rhyzobial and actinorhiza) are observed only in plants with "long variant" of SYMRK gene. Arbuscular mycorrhiza is revealed for all three variants of the gene which was proven in experiments on mutant form of Lotus japonikus, having neither AM nor RLS. Transfer of "middle variant" of SYMRK gene of tomato and "short variant" of gene of rice restored capability of forming AM but not RLS. Transfer of "long variant" of gene from alfalfa, creating RLS, from Datisca glomerata, which has symbiotic association with actinobacteria, and from non-nodulating Tropaeolum majus resulted in restoration of both AM and RLS in mutant Lotus. The authors suggested their hypothesis on capability of genetic programme of AM to be the foundation of forming actinorhiza and RLS. Thus, "genetic programme" of rhizobial symbiosis is 
modification of "genetic programme" of arbuscular mycorrhiza [27].

Proteins, synthesized de novo, emerge in cells, which participate in symbiosis. Some of them are common for both AM and rhizobia-legume association. These are proteins of peri-bacteroid and peri-arbuscular membranes, some early nodulines (ENOD2, ENOD11, ENOD12), and a small amount of leghemoglobin. Formation of both types of associations is stimulated by lipochito-oligosaccharide Nod-factors [28].

Investigation on genetic control of AM development proved that mutations in genes sym8, sym9, sym19, sym30, sym33, and sym40 disrupt mycorrhization of Pisum. These genes also stimulate nodulation in leguminous-rhizobia association [29, 30]. Over-expression of ENOD40 gene results in increased formation of arbuscula [31]. The plant regulates the degree of AM colonization, and there are data evidencing participation of harl gene, coding HAR1-receptor of kinase, in this process [32]. The study on L. japonicus showed that introduction of hyphae into plant cells is promoted by LjSYM4 and LjSYM15 genes; activation of intracellular assimilation programme is mediated by LjSYMRK and LjSYM4 genes $[33,34]$. Degradation of arbuscula may be controlled by plant gene Prp1, encoding glutathione-S-transferase, while Mtaqpl gene, which is located in tonoplasts and encodes aquaporin, is responsible for restoration of osmotic status of cells, that was disrupted due to degradation of vacuole [35].

Recent application of transcriptome analysis allowed investigation of hundreds of new genes in different species of plants which are activated as a result of fungal association with plant roots [36]. There is a hypothesis concerning possible existence of a genetic system in legumes that controls development of double symbiosis: fungi of arbuscular mycorrhiza rhizobia [37].

Activation of processes taking place in a plant cell in response to penetration of Glomus mycelium is similar to cell reaction to the attack of pathogens. It also induces synthesis of phytoalexins, callose, peroxidases, lytic enzymes, protective proteins, and modification of the cell wall. However, processes taking place in AM are less intense and more differentiated in space and time. Activity of lytic enzymes is revealed only in case of epidermis infecting, while in colonization of cortex and formation of arbuscula their level decreases to initial values. Some data testify to probable relation of this fact to fungal expression of signal factors to repress the activity of the mentioned enzymes [38, 39].

As of today, symbiosis of legumes and microorganisms, forming both arbuscular mycorrhiza and nitrogen-fixing tubercles, has been investigated the most [40].

Leguminous-rhizobia symbiosis. At the beginning of 1990s exchange of chemical signals between legumes and rhizobia causing infection of root fibrils and further formation of tubercles was called "molecular dialogue" [41]. The development of this symbiotic association has several stages, namely, pre-infection, infection of roots, nodulation, and tubercles functioning as nitrogen-fixing organs.

The process of infecting roots takes place via root fibrils which curl, taking the form of an "umbrella handle" (Hac stage - Hair curling). A cell wall degrades in the place of curling which causes protruding of plasmalemma. Root fibrils seem to capture bacteria with subsequent emerging of infection thread (IT). Walls of IT are composed of plant cells, and matrix content is the common product of plants and bacteria (Itf stage - Infection thread formation). IT development goes along with formation of tubercular primordium which takes place due to initiation of mitotic reactivation, dedifferentiation, and proliferation of cortex cells by Nod-factors (Ccd stage - Cortical cell division). Histogenesis of primordium leads to apical meristem, as well as peripheral (surface and conductive) and central (containing bacteria) tubercular tissues. Growing IT passes through a root fibril and penetrates cortex and tubercle. Here the main stage is bacteria transfer inside the cell via endocytosis (Bar stage Bacterial release). In this case distal parts of IT transform into special structures - infectious drops without a cell wall, which open the way for membrane vesicles, containing bacteria, into plant cytoplasm. Therefore, bacteria are not located at random within plant cytoplasm, but inside peribacteroid membranes (PBM), created with participation of Golgi apparatus and endoplasmatic reticulum, which contain bacterial proteins. 
A bacterium, surrounded by PBM, is the main intracellular unit of symbiosis, - a symbiosome, responsible for provision of plants with nitrogen [42]. After leaving infectious thread rhizobia preserve their sizes and rod-like shape for some time; then they transform into special structures - bacteroides (Bad stage Bacteroid differentiation). Such transformation of microorganisms leads to subsidence of some genes, vital for autonomous existence, and bacteroides cannot transform info free forms living outside a tubercle any more [43]. Above mentioned processes result in formation of a tubercle with the following constituents: apical meristem, providing growth of a tubercle, central part, where fixation of nitrogen takes place, and peripheral conductive bundles responsible for two-way conductivity.

Bacteroides are characterized by synthesis of nitrogenase (Nif stage - Nitrogen fixation) - the central enzyme of nitrogen fixation, catalyzing restoration of molecular nitrogen to ammonium, which is a complex of structurally and functionally conservative metalloenzymes. This complex consists of two components, namely, iron-containing ATP-depended nitrogenase reductase (Fe-protein) and dinitrogenase, containing iron and molybdenum (MoFe-protein). Dimeric Fe-protein $\left(\gamma^{2}\right)$ is a donor of electrons for a larger heterotetramer MoFe-protein $\left(\alpha^{2} \beta^{2}\right)$, where subunits $\alpha, \beta, \gamma$ are encoded by nifD, nifK, and nifH genes, respectively. All nitrogen fixers are characterized by MoFe-nitrogenase system (nitrogenase I), but if the amount of molybdenum is insufficient and vanadium is present, vanadium-containing V-nitrogenase (nitrogenase II) is expressed, and if these metals are absent, Fe-nitrogenase, containing iron only (nitrogenase III) is expressed.

It should be noted that the process of nitrogen fixation is energy-dependent requiring ATP presence [44, 45]. The amount of membrane structures in plant cells increases with polyploidization and chromatin unwinding which is related to intensification of transcription activity. This is the time of leghemoglobin synthesis that is a specific result of symbiosis: prosthetic group is synthesized by bacteroides, while plants participate in the synthesis of a protein component. Leghemoglobin binds oxygen to oxygenated form $\mathrm{LbO}_{2}$ and provides its transportation to symbiosome. At the same time ox- ygen is in bound state which enables aerophobic nitrogenase to work actively in microaerobic conditions [46].

The process of plant recognition by rhizobia starts with recognizing flavonoids i.e. secondary metabolites of plants, expressed by growing seeds and roots of plants [47]. Flavonoids have a gene-inducing function which reveals at their micromolar concentrations [48, 49]. There are data evidencing the fact that one flavonoid may serve as an inductor for some rhizobia and as an inhibitor - for others. For instance, daidzein and genistein induce B. japonicum and Rhizobium sp. NGR234, but are inhibitors for $R$. leguminosarum bv. trifolii and bv. viciae [50, 51].

Flavonoids are characterized by considerable variety. About 30 flavonoids, stimulating expression of nod-genes, were isolated from nine species of legumes [52].

Primary interaction takes place between flavonoids and protein of nodD gene. NODD protein activates the system of virulence genes of rhizobia which are responsible for synthesis of lipochito-oligosaccharide Nod-factors. Recent studies revealed that Nod-factor initiates production of cytokinin in the roots of legumes via calcium-dependent signal ways. In its turn, cytokinin stimulates division of cortical cells on association parts of a tubercle [53].

Special features of molecular structure of Nod-factors play a significant role in determining specificity of further interaction as a whole. For instance, endogenous isoflavonoids of soya are capable of inducing nod-genes of $B$. japonicum after a bacterium penetrated root fibrils of a plant [54]. The main nodulation factor for Sinorhizobium meliloti (NodRm-1) is sulphated and acylated glycosamine tetrasaccharide [55]. There is a supposition that NODG, NODE, and NODF proteins participate in the synthesis of acyl chain, while NODPQ and NODH take part in sulfation of a nodulation factor. nod $A B C$ genes are common for all kinds of rhizobia; they encode cortical part of a Nod-factor molecule. Other genes, including nodPQ, $n o d H$, nodEF, and nodX, are species- or even strain-specific. They control modifications of chemical structure of Nod-factor, determining specificity of further interaction. nodPQ and nodH genes, revealed in legume bacteria of alfalfa (S. meliloti) determine attach- 
ment of a sulphate group, necessary to induce formation of tubercles, to Nod-factor. Inactivation of these genes makes bacteria lose their capability to inoculate alfalfa, but a possibility of causing early symbiotic reactions in some non-specific host e.g. vetch - still remains [56].

Flavonoids of plants influence DNA synthesis via binding with promoter part (Nod-box) of an inducible gene, therefore initiating RNA-polymerase to start transcription [57]. However, not all flavonoids initiate transcription. Among several flavonoids of S.meliloti only luteolin was capable of causing expression of a nod-gene [58]. The determination of regulating mechanism showed that 36 nod-genes, induced by flavonoids, are not expressed at the same time. Nod-factor is the first to be synthesized, followed by proteins of III type, and lipopolysaccharide (LPS), rich in rhamnose, is produced later [59].

Similar to nod-genes, nif- and fix-genes also play an important role in the process of symbiosis. The structure of the former is homologous to that of nif-genes of Gammaproteobacteria Klebsiella pneumoniae, nitrogen fixation genes of which have been studied for the first time. These are the genes, necessary for biosynthesis of nitrogenase and regulatory proteins [60]. Fix-genes are also essential for nitrogen fixation, still they may exist in non-nitrogen-fixing organisms as well. Sequencing and mutational analysis of nif- and fix-genes revealed both similar structure and functions of their products in many diazotrophs and some divergence in their origin [61].

Four years ago it was reported about identification of a set of 756 genes, expressed more or less intensively during infection of root cells, nodulation, functioning and protective response in symbiotic interaction of $M$. truncatula and S. meliloti. Four main groups of genes with differentiated expression were defined as follows: 1) genes causing intensive expression in young and ripe tubercles; 2) genes activated in ripe nods; 3) genes induced transiently after 3-4 days following the inoculation; 4) genes causing decreased expression during nodulation [62].

Initiation of nod-genes expression is specific for non-flavonoid substances as well. Components with stimulating capacities in lupine seeds are aldonic acid, erythronic acid, and tetronic acid [63]. Usually the plant jasmonates are considered as inducers of genes, acting in response to an injury or attack of pathogens, but they may also stimulate expression of nod-genes of B. japonicum both independently and in combination with a flavonoid inducer [64]. Xanthans initiate transcription of nod-gene of B. japonicum [65].

In common with AM, initiated nod-genes produce Nod-factors, which are various lipochito-oligosaccharides, enabling rhizobia to penetrate into the roots of legumes. They participate in deformation of root fibrils, depolarization of membrane plasma, changes in cytoskeleton of root fibrils, formation of pre-infection thread, cortical division of cells in parts of nodulation premordia, inhibition of reactive system of oxygen production, disorder of auxin metabolism in roots, induction of plant nodulins, infection, formation, and functioning of tubercles in symbiosis [66].

Nod-factors are also involved in the formation of a thin $(1-10 \mu \mathrm{m})$ layer of amorphous mucous material mucigel i.e. biofilm which is a complex substrate with many components - on the surface of plant roots (root cap, rhizodermis, root fibrils, etc). Electronic microscopy was used to show presence of fibrillar cells in the point of contact of rhizobia and root surface which proved the formation of biofilm [67]. The latter consists of extracellular polysaccharides, LPS, K-polysaccharides, and cyclic glucans, and is vital both for formation of immune response of a plant and for protection against active oxygen. Besides, the surface of microorganisms hosts O-specific chains of LPS, integrated into the outer membrane of bacteria. Polysaccharides of polysaccharide-lipid complexes contain ramnose, galactose, galacturonic acid, small amounts of $\mathrm{N}$-acetyl-D-glucosamine, mannose, fucose, xylose, and glucose in different ratio.

A new high-molecular polysaccharide RBL5523, isolated recently from $R$. leguminosarum bv. viciae, mainly contains glucose, mannose, and a small amount of galactose and ramnose, and demonstrates high capacity of binding to lectin of pea and vetch ( $V$. sativa). The authors suppose this polysaccharide to be important for primary attachment to root fibrils [68].

The following stage of symbiotic association of bacteria and plants is interaction of plant lectins and bacterial polysaccharides. The ffirst data on exchange of plant-microbial signals were obtained from investi- 
gation on lectins of legumes as factors of forming highly specific rhizobial symbiosis [69]. Numerous experimental data concerning the influence of plant lectins on metabolism of eukaryotic cells bring evidence to the fact that these carbon-binding proteins have inherent properties of signal molecules. Bacterial lectins (agglutinins of cellular surface of associative and symbiotic microorganisms) participate in the process of symbiosis along with phytolectins [70]. Similar to agglutinins of microorganisms, plant lectins promote fixation of microorganism of plant tissues and influence metabolism of a partner [71].

Besides, both AM and rhizobia have several other components, necessary for successful colonization of roots and further nodulation or increased growth of a plant before nitrogen fixation starts. For instance, this is indolacetic acid (IAA), synthesis of which is flavonoid-dependent and controlled by Nod-box NB15 in Rhizobium sp. NGR234. Absence of IAA in a mutant strain makes nodulation more complicated [72].

Pentacyclic triterpenoid lipids - hopanoids - enhance resistance of bacteria against biotic and abiotic stresses and strengthen the membrane. It was determined that expression of synthetic gene of hopanoid of Rhizobium sp. NGR234 depends on flavonoid and Nod1-factor and is controlled by Nod-box NB1 which may determine symbiotic functioning of these components [73]. The data on lumichrome of $S$. meliloti prove its role in enhancing root breathing and improving growth of $M$. sativa [74].

Similar to AM, development of legume-rhizobial symbiosis is regulated by a host plant, providing optimal amount and biochemical activity of endosymbionts, which does not allow symbiosis to become a pathogenic process. The function of phenols, synthesized in tubercles, flavonoids, and active forms of oxygen is not inhibition of microorganisms, but regulation of their activity. Presence of a system, controlling development of different forms of symbiosis, in plants may be used in elaborating methods of biocontrol over pathogens using microbe preparations.

Associative bacteria. Besides above mentioned symbiotic associations, much attention is currently paid to interaction of plants and plant growth-promoting bacteria (PGPB), when a specific ecosystem with morphologically unclear, yet mutually beneficial func- tional relations is established. Microbiologists call these relations associativity, and microorganisms in such association are called associative, respectively [75]. This pertains to representatives of Azotobacteriaceae, Bacillaceae, Enterobacteriaceae, Pseudomonadaceae, Spirillaceae genera. These bacteria colonize a number of non-leguminous plants (Gramineae, first of all), widespread in different climatic zones.

Formation of PGPB association with a plant follows stages, similar to those of classic symbiotic associations, - chemotaxis, lectin-carbohydrate interaction, surface colonization (of some internal organs of a plant, in some cases), and the stage of establishing relations, determined by the exchange of substances, useful both for a plant, and for microorganism.

Comparison of associative microflora and symbiotic one reveals the former to have lower efficiency of nitrogen-fixation; however, these bacteria have important capacities, vital for growth and development of a plant, namely, solubilization of phosphates, decrease in the amount of ethylene, promotion of absorption of potassium, nitrogen, and iron from soil, as well as synthesis of a number of vitamins (riboflavin, thiamine, pantothenic acid, etc) $[5,14,76,77]$. Multitude of PGPB produce substances, inhibiting pathogenic microflora and promoting formation of induced systemic resistance (ISR) in plants, which protects them from phytopathogens (viruses, bacteria, and fungi) [78-80]. Investigation on IRS in the association of A. thaliana $-P$. thivervalensis revealed that bacterial infection leads to the change in the level of expression of genes of Arabidopsis, which defines response to the oxidative stress, injury, resistance against diseases, and also to encoding of proteins with non-determined functions [81, 82].

The study of aforesaid associations called attention to microorganisms, belonging to Azospirillum genus. Besides $A$. brasilense, A. lipoferum, and A. irakense, which were rather well known, a new strain of Azospirilla-A. canadense - has recently been isolated and characterized; it is capable of fixing nitrogen in association with roots of corn [83].

Azospirilla form both surface and intratissue associations. A irakense usually binds with root fibrils of rice, while $A$. brasilense is located on the root surface [84]. 
The process of $A$. brasilence attaching to wheat (Trirucum aestivum) may have two stages [85]. The first stage is weak, reversible, and non-specific attachment, determined by plant lectins, bacterial surface proteins, capsule polysaccharides, and flagella. The second stage of attachment is non-reversible. It is mediated by bacterial surface polysaccharides.

Mobility of bacterial cells is of great importance to association formation. There are three types of mobility concerning Azospirilla. They swim in liquid medium (Fla ${ }^{+}$-phenotype), group together in more dense media (Swa ${ }^{+}$-phenotype) or spread slowly ( $\mathrm{Gri}^{+}$-phenotype). Single polar flagella are formed on cells of all kinds of Azospirilla in media of different density. Certain degree of viscosity in the medium causes production of numerous lateral flagella (Laf) in $A$. brasilense, A. lipoferum, and $A$. irakense, which are shorter, thinner, and different serologically compared to polar flagella [86]. Besides, polar flagellum participates in adsorption of Azospirilla on plant roots. Insertion mutagenesis revealed that genes of $A$. brasilense $\mathrm{Sp} 245$, determining collection and work of flagella, are located in six parts of bacteria genome at least, scattered along plasmid and chromosome DNA [87].

Adsorption capacity is another criterion characterizing efficiency of association. This parameter pertains to the level of producing surface polymers, participating in contact associations of partners [88]. Some vital factors controlling this process are $\mathrm{pH}$ of medium and presence of bivalent cations [89].

However, adhesive properties of lectins are supposed to play the main role at the contact of bacteria and cells of plant roots which reveals in association with specific polysaccharides of mucigel.

Considerable amount of data on lectins was obtained on the example of wheat sprouts lectin (agglutinin of wheat germs - AWG). In particular, lectin of wheat is a molecular signal for Azospirilla of $A$. brasilense and A. lipoferum, since it initiates processes necessary for formation and functioning of their association [90]. It was determined that similar to eukaryotes, cellular response of $A$. brasilense Sp245 to AWG is pleiotropic i.e. includes at least 12 separate effects. Lectin initiates processes of nitrogen fixation, production of IAA, biosynthesis of glutamin synthase; it also influences growth of bacteria and non-specific increase in biosynthesis of cellular proteins [91].

Binding of lectin with the surface of bacteria results in enhanced exposure of hemagglutinin and $\mathrm{O}$-specific polysaccharide-containing polymers (LPS-protein complexes and polysaccharide-lipid complexes of capsule and membrane LPS) [92], as well as an increase in the amount of surface-associated hemolytic factor on cells of bacteria. It is probable that hemolysin is also involved in the process of bacterial colonization of a host plant [93].

A great variety of structures were revealed among investigated O-specific polysaccharides (O-PS). Some strains have a recurrent pentasaccharide link, others have hexaoligosaccharides, consisting of rhamnose, mannose, and substitutes of non-carbohydrate nature [94]. Polysaccharide complexes are capable of associating with AWG, and inducing deformation of root fibrils of wheat sprouts together with LPS [89]. Two kinds of O-PS were revealed for $A$. brasilense Sp245: neutral and acid. Lipopolysaccharide Km252 contains only the neutral kind, while $\mathrm{Km} 018$ has only acid O-PS. Treatment of wheat roots with LPS preparations, isolated from Sp245 cells and its omegon Lps-mutants, induced deformation of root fibrils. Deformation activity of LPS Sp245 was significantly higher compared to $\mathrm{Km} 252$ and KM018. Use of Lps-mutant of Km252 for inoculation of wheat sprouts allowed obtaining additional proof to LPS participation in adsorption of Azospirilla on the plant roots [94, 95].

It takes some time for Azospirilla to give either short-term or prolonged response to lectin of plants. Thus, in 3-4 hours following association there is increase in biosynthesis of cellular proteins and induction of synthesis of new proteins. Bacterial cells enlarge [96]. The process of nitrogen fixation is induced due to activation of nitrogenase complex; transportation of ammonium from the cell into the medium of bacterium is enhanced. There is a change in the ratio of acid phospholipids, phosphatidyl glycerol and phosphatidyl choline in the membranes of bacteria [97]. Prolonged symbiotic responses are increased in the amount of cells due to the influence of lectin and stimulation of IAA production by Azospirilla [98, 99]. The main condition of IAA synthesis by rhizospheral bacteria is the availability of its predecessor - tryptophan - in root 
exudates [100]. Inactivation of ipdC gene, encoding indole-3-pyruvate decarboxylase (key enzyme in one of the ways of IAA biosynthesis), results in the decrease in IAA production by about $10-50 \%$ of the wild type level $[101,102]$. It was shown that the protein of ipdC gene is also involved in biosynthesis of phenylacetic acid, auxin of anti-bacterial activity. A. brasilense, mutant in ipd gene, shows a considerably decreased level of phenylacetic acid [103].

It is possible that bacteria use auxin as an element of plant cell colonization, causing phytostimulation effect and inhibition of the main protection mechanisms of a plant [104]. For instance, this phytohormone may detoxicate some analogues of tryptophan or its non-physiological concentrations, inhibiting the growth of bacteria [105]. Inducing role of another phytohormone - gibberellin acid - was shown in initiating expression of two genes of rice Oryza sativa [106].

The data on associations between microorganisms and plant cells in rhizosphere are constantly accumulated. Probably, there is a possibility for future gene-engineering construction of rhizosphere, for instance, in case of creation of plants with definite composition of root exudates, which could draw useful microorganisms to rhizosphere and inhibit development of harmful bacteria [107].

Recent 20 years have witnessed significant clarification of "the molecular dialogue", nevertheless, much is yet to be specified.

The main features of formation of AM, legume-rhizobial association, and associative interaction of non-legumes and endophytic Azospirilla are similar stages of forming symbiotic interaction, common molecular and genetic mechanisms of response (general genes of symbiosis), appearance of link due to protein-polysaccharide interaction, biofilm formation, dependence of association on many physiological factors, etc. Rhizosphere bacteria react to chemoattractants of root exudates, capable of stimulating nod-genes. Specific proteins of bacteria play an initiating role in the interaction, but their functions are yet to be studied further.

Plant lectins and their association with bacterial polysaccharides are of great importance to the bacterial infection of roots. A general hypothesis has been proposed concerning specific lectin recognition, which ex- plains molecular mechanisms of bacteria attaching to plant roots. Though there are many ambiguous data on a definite role of lectins, there is no doubt about importance of these proteins for the plant-microorganism association.

Intensity of symbiotic association depends on many physiological factors, namely, age of culture, composition and acidity of medium, cell mobility, etc., which may vary considerably and play a decisive role in the formation of various symbiotic associations.

The data obtained on association of a plant and a bacterial component of symbiotic and associative complexes prove the efficient and flexible system of mutual coordination and regulation between them. The result of exchange of specific signals between microorganisms and plant cells in rhizosphere is molecular-genetic response as well as biochemical, morphological, and physiological changes in each symbiont, directed towards optimization of functioning of association participants as an integral consistent organism.

\section{Л. Г. Льошина}

Клітинні і молекулярно-генетичні механізми симбіозу та асоціативної взаємодії мікроорганізмів з рослинами у ризосфері

Резюме

Розглянуто результати досліджень взаємодії мікроорганізмів і рослин у ризосфері. Особливу увагу приділено прочесу контактної асочіації клітин мікроорганізмів $і$ тканин рослин за участі конкретних молекулярних структур, у якому домінантна роль приділяється білково-вуглеводним взаємовідносинам. Відзначено загальні риси та відмінності у формуванні арбускулярної мікоризи, бобово-ризобіального симбіозу та асоціації небобових рослин з азоспірилами.

Ключові слова: симбіоз, асочіативна взаємодія, арбускулярна мікориза, ризобії, азоспірили.

\section{Л. Г. Лёшина}

Клеточные и молекулярно-генетические механизмы симбиоза и ассоциативного взаимодействия микроорганизмов с растениями в ризосфере

Резюме

Рассмотрены результаты исследований по симбиотическому и ассоииативному взаимодействию микроорганизмов и растений в ризосфере. Особое внимание уделено процессу контактной ассоциации клеток микроорганизмов и тканей растений с участием конкретных молекулярных структур, в ходе которого доминантная роль отводится белково-углеводным взаи- 
моотношениям. Отмечены общие черты и различия при формировании арбускулярной микоризы, бобово-ризобиального симбиоза и ассоцииации небобовых растений и азоспирилл.

Ключевые слова: симбиоз, ассочиативное взаимодействие, арбускулярная микориза, ризобии, азоспирилльл.

\section{REFERENCES}

1. Tetz V. V. Pangenom // Tsitologia.-2003.-45, N 5.-P. 526531.

2. Provorov N. A., Borisov A. Y., Tikhonovich I. A. Comparative genetics and evolutionary morphology of symbioses formed by plants with nitrogen-fixing microbes and endomycorrhizal fungi // Zhurnal Obshchei Biologii.-2002.-63, N 6.- P. 451472.

3. Kent A. D., Triplett E. W. Microbial communities and their interaction in soil and rhizosphere ecosystems // Annu. Rev. Microbiol.-2002.-56, N 1.-P. 211-236.

4. Lutova L. A., Provorov N. A., Tikhodeev O. N., Tikhonovich I. A., Khodzhaiova L. T., Shishkova S. O. Genetics of plant development // Ed. S. G. Inge-Vechtomov.-M.: Nauka, 2000.$539 \mathrm{p}$.

5. Hurek T., Reinhold-Hurek B. Azoarcsus sp. strain BH72 as a model for nitrogen-fixing grass endophytes // J. Biotechnol.2003.-106, N 2/3.-P. 169-178.

6. Ryu C. M., Farag M. A., Hu C. H., Reddy M. S., Wei H. X., Pare P. W., Kloepper $J$. $W$. Bacterial volatiles promote growth in Arabidopsis // Proc. Nat. Acad. Sci. USA.-2003.-100, N 8.-P. 4927-4932.

7. Somers E., Vanderleyden J., Srinivasan M. Rhizosphere bacterial signalling: a love parade beneath our feet // Crit. Rev. Microbiol.-2004.-30.-P. 205-240.

8. Krishnan H. B., Bennett J. O. Rhizobium-legume symbioses: molecular signals elaborated by rhizobia that are important for nodulation // Plant-Associated Bacteria / Ed. S. S. Gnanamanickam.-Amsterdam: Springer, 2006.-P. 57-104.

9. Cooper J. E. Early interactions between legumes and rhizobia: disclosing complexity in a molecular dialogue // J. Appl. Microbiol.-2007.-103.- P. 1355-1365.

10. Wall L. G. The actinorhizal symbiosis // J. Plant Growth Regul.-2000.-19.-P. 167-182.

11. Kuhn G., Hijri M., Sanders I. R. Evidence for the evolution of multiple genomes in arbuscular mycorrhizal fungi // Nature.2001.-414.-P. 745-748.

12. Pawlowska T. E., Taylor J. W. Organization of genetic variation in individuals of arbuscular mycorrhizal fungi // Nature.-2004.-427.-P. 733-737.

13. Harrison M. J. The arbuscular mycorrhizal symbiosis // Plant-microbe interaction / Eds G. Stacey, N. T. Keen.-New York: Chapman and Hall, 1997.-P. 1-34.

14. Katzy E. I. Molecular-genetic processes that affect the associative interaction of soil bacteria with plants / Ed. V. V. Ignatov.-Saratov: SGU, 2003-172 p.

15. Strack D., Fester T., Hause B., Schliemann W., Walter M. H. Arbuscular mycorrhiza: biological, chemical, and molecular aspects // J. Chem. Ecol.-2003.-29.-P. 1955-1979.

16. Bago B., Pfeffer P. E., Shachar-Hill Y. Carbon metabolism and transport in arbuscular mycorrhizas // Plant Physiol.2000--124.-P. 949-958.

17. Smith S. E., Dickson S., Smith F. A. Nutrient transfer in arbuscular mycorrhizas: how are fungal and plant processes integrated? // Austr. J. Plant Physiol.-2001.-28.-P. 683-694.
18. Day D. A., Kaiser B. N., Thomson R., Udvardi M. K., Moreau $S$., Puppo A. Nutrient transport across symbiotic membranes from legume nodules // Austr. J. Plant Physiol.-2001.-28.P. 667-674.

19. Parniske $M$. Intracellular accommodation of microbes by plants: a common developmental program for symbiosis and disease? // Curr. Opin. Plant Biol.-2000.-3.-P. 320-328.

20. Genre A., Chabaud M., Timmers T., Bonfante P., Barker D. $G$. Arbuscular mycorrhizal fungi elicit a novel intracellular apparatus in Medicago truncatula root epidermal cells before infection // Plant Cell.-2005.-17.-P. 3489-3499.

21. Lum M. R., Hirsch A. M. Roots and their symbiotic microbes: strategies to obtain nitrogen and phosphorus in a nutrientlimiting environment // J. Plant Growth Regul.-2002.-21.P. 368-382.

22. Parniske M. Molecular genetics of the arbuscular mycorrhizal symbiosis//Curr. Opin. Plant Biol.-2004.-7.-P. 414-421.

23. Limpens E., Bisseling T. Signaling in symbiosis // Curr. Opin. Plant Biol.-2003.-6.-P. 343-350.

24. Geurts R., Fedorova E., Bisseling T. Nod-factor signaling genes and their function in the early stages of Rhizobium infection // Curr. Opin. Plant Biol.-2005.-8.-P. 346-352.

25. Stacey G., Libault M., Brechenmacher L., Wan J., May G. D. Genetics and functional genomics of legume nodulation // Curr. Opin. Plant Biol.-2006.-9.-P. 110-121.

26. Kistner C., Winzer T., Pitzschke A., Mulder L., Sato S., Kaneko T., Tabata S., Sandal N., Stougaard J., Webb K. J., Szczyglowski K., Parniske M. Seven Lotus japonicus genes required for transcriptional reprogramming of the root during fungal and bacterial symbiosis // Plant Cell.-2005.-17.P. 2217-2229.

27. Gherbi H., Markmann K., Svistoonoff S., Estevan J., Autran D., Giczey G., Auguy F., Peret B., Laplaze L., Franche C., Parniske M., Bogusz D. SymRK defines a common genetic basis for plant root endosymbioses with arbuscular mycorrhiza fungi, rhizobia, and Frankiabacteria // Proc. Nat. Acad. Sci. USA.-2008.-105, N 12.-P. 4928-4932.

28. Xie Z.-P., Muller J., Wiemken A., Broughton W. J., Boller T. Nod factors and tri-iodobenzoic acid stimulate mycorrhizal colonization and affect carbohydrate partitioning in mycorrhizal roots of Lablab purpureus // New Phytologist.-1997.139.-P. 361-366.

29. Borisov A. Y., Jacobi L. M., Lebsky V. K., Morzhina E. V., Tsyganov V. E., Voroshilova V. A., Tikhonovich I. A. Pea (Pisum sativum L.) genetic system controlling development of nitrogen-fixing nodules and arbuscular mycorrhiza // New approaches and techniques in breeding sustainable fodder crops and amenity grasses / Eds N. A. Provorov, I. A. Tikhonovich, F. Veronesi.-St-Petersburg: VIR publ., 2000.P. 231-236.

30. Jacobi L. M., Zubkova L. A., Barmicheva E. M., Tsyganov V. E., Borisov A. Y., Tikhonovich I. A. Effect of mutations in the pea genes Sym 33 and Sym 40. II. Dynamics of arbuscule development and turnover // Mycorrhiza.-2003.-13.-P. 9-16.

31. Staehelin C., Charon C., Boller T., Crespi M., Kondorosi A. Medicago truncatula plants overexpressing the early nodulin gene enod40 exhibit accelerated mycorrhizal colonization and enhanced formation of arbuscules // Proc. Nat. Acad. Sci. USA.-2001.-98.-P. 15366-15371.

32. Solaiman M. Z., Senoo K., Kawaguchi M., Imaizumi-Anraku H., Akao S., Tanaka A., Obata H. Characterization of mycorrhizas formed by Glomus sp. on root of hypernodulating mutants of Lotus japonicus // J. Plant Res.-2000.-113.-P. 443448. 
33. Demchenko K., Winzer T., Stougaard J., Parniske M., Pawlowski $K$. Distinct roles of L. japonicus SYMRK and SYM15 in root colonization and arbuscule formation // New Phytologist.-2004.-163.-P. 381-392.

34. Novero M., Faccio A., Genre A., Stougaard J., Webb K. J., Mulder L., Parniske M., Bonfante P. Dual requirement of the LjSym 4 gene for mycorrhizal development in epidermal and cortical cells of Lotus japonicus roots // New Phytologist.2002.-154.-P. 741-749.

35. Franken $P$., Requena $N$. Analysis of expression in arbuscular mycorrhizas: new approaches and challenges // New Phytologist.-2001.-150.-P. 517-523.

36. Hohnjec N., Henckel K., Bekel T., Gouzy J., Dondrup M., Goesmann A., Kuster H. Transcriptional snapshots provide insights into the molecular basis of arbuscular mycorrhiza in the model legume Medicago truncatula // Funct. Plant Biol.2006.-33.-P. 737-748

37. Borisov A. Y., Danilova T. N., Koroleva T. A., Naumkina T. S., Pavlova Z. B., Pinaev A. G., Shtark O. Y., Tsyganov V. E., Voroshilova V. A., Zhernakov A. I., Zhukov V. A., Tikhonovich I. A. Pea (Pisum sativum L.) regulatory genes controlling development of nitrogen-fixing nodule and arbuscular mycorrhiza: fundamentals and application // Biologia.-2004.59, N 13.-P. 137-144.

38. Shaul O., David R., Sinvani G., Ginzberg I., Ganon D., Wininger S., Ben-Dor B., Badani H., Ovdat N., Kapulnik Y. Plant defense responses during arbuscular mycorrhiza symbiosis // Current advances in mycorrhizal research / Eds G. K. Podila, D. D. Douds.-St. Paul: Amer. Phytopathol. Soc. press, 2000.-P. 61-68.

39. Yedidia I., Benhamou N., Kapulnik Y., Chet I. Induction and accumulation of PR proteins activity during early stages of root colonization by the mycoparasite $T$. harzianum strain T-203 // Plant Physiol. Biochem.-2000.-38.- P. 1-11.

40. Rodriguez-Navarro D. N., Dardanelli M. S., Ruiz-Sainz J. E. Attachment of bacteria to the roots of higher plants // FEMS Microbiol. Lett.-2007.-272, N 2.-P. 127-136.

41. Denarie J., Debell F., Truche G., Prome J.-C. Rhizobium and legume nodulation: a molecular dialogue // New horizons in nitrogen fixation / Eds R. Palacios, J. Mora, W. E. Newton.Dordrecht: Kluwer, 1993.-P. 19-30.

42. Roth L. E., Stacey G. Bacterium release into host cells of nitrogen-fixing soybean nodules: the symbiosome membrane comes from three sources // Eur. J. Cell. Biol.-1989.-49, N 1.-P. 13-23.

43. Quispel A. Evolutionary aspects of symbiotic adaptations: Rhizobium's contribution to evolution of associations // The Rhizobiaceae / Eds H. Spaink, A. Konodorosi, P. J. J. Hooykaas.-Dordrecht; Boston; London: Kluwer Acad. publ., 1998.-P. 487-507.

44. Ljones $T$. Nitrogen fixation and bioenergetics: the role of ATP in nitrogenase catalysis // FEBS Lett.-1979.-98, N 1.P. $1-8$.

45. Bertsova $Y$. V., Demin O. V., Bogachev A. V. The respiratory protection of the nitrogenase complex in Azotobacter vinelandii // Uspekhi Biol. Khimmii.-2005.-45.-P. 205-234.

46. Kaminski P. A., Batut J., Boistard P. A survey of symbiotic nitrogen fixation by rhizobia // The Rhizobiaceae / Eds H. Spaink, A. Konodorosi, P. J. J. Hooykaas.-Dordrecht; Boston; London: Kluwer Acad. publ., 1998.-P. 431-460.

47. Aoki T., Akashi T., Ayab S. Flavonoids of leguminous plants: structure, biological activity, and biosynthesis // J. Plant Res.-2000.-113.-P. 475-488.
48. Subramanian S., Stacey G., Oliver Y. Distinct, crucial roles of flavonoids during legume nodulation // Trends Plant Sci.2007.-12, N 7.-P. 282-285

49. Begum A., Leibovitch S., Migner P., Zhang F. Specific flavonoids induced nod gene expression and pre-activated nod genes of Rhizobium leguminosarum increased pea (Pisum sativum L.) and lentil (Lens culinaris L.) nodulation in controlled growth chamber environments // J. Exp. Bot.2001.-52.-P. 1537-1543

50. van Brussel A. A. N., Recourt K., Pees E., Spaink H. P., Tak T., Wijffelman C., Kijne J., Lugtenberg B. J. J. A biovarspecific signal of Rhizobium leguminosarum bv. viciae induces increased nodulation gene-inducing activity in root exudate of Vicia sativa subsp. Nigra // J. Bacteriol.-1990.172.-P. 5394-5401.

51. Schmidt P., Broughton W., Werner D. Nod factors of Bradyrhizobium japonicum and Rhizobium sp. NGR234 induce flavonoid accumulation in soybean root exudates // Mol. PlantMicrobe Interact.-1994.-7.-P. 384-390.

52. Cooper J. E. Multiple responses of rhizobia to flavonoids during legume root infection // Adv. Bot. Res.-2004.-41.P. 1-62.

53. Oldroyd G. E. D. Nodules and hormones // Science.-2007.315.-P. 52-53.

54. Subramanian S., Stacey G., Yи O. Endogenous isoflavones are essential for the establishment of symbiosis between soybean and Bradyrhizobium japonicum // Plant J.-2006.48.-P. 261-273.

55. Lerouge P., Faucher C., Maillet F., Truchet G., Prome J. C., Denarie J. Symbiotic host specificity of Rhizobium meliloti is determined by a sulphated and acylated glucosamine oligosaccharide signal // Nature.-1990.-344, N 6268.-P. 781-784.

56. Ovtsyna A. O., Tikhonovich I. A. Structure, functions and possibility of the practical application of the signal molecules, initiating development rhizobium-legume symbioses // Ecol. Genetika.-2004.-1.-P. 36-46.

57. Chen X.-C., Feng J., Hou B.-H., Li F.-Q., Li Q., Hong G.-F. Modulating DNA bending affects NodD-mediated transcriptional control in Rhizobium leguminosarum // Nucl. Acids Res.-2005.-33.-P. 2540-2548.

58. Peck M. C., Fisher R. F., Long S. R. Diverse flavonoids stimulate NodD1 binding to nod gene promoters in Sinorhizobium meliloti // J. Bacteriol.-2006.-188.-P. 5417-5427.

59. Kobayashi H., Naciri-Graven Y., Broughton W. J., Perret X. Flavonoids induce temporal shifts in gene expression of nod-box controlled loci in Rhizobium sp. NGR234 // Mol. Microbiol.-2004.-51.-P. 335-347.

60. Dixon R., Kahn D. Genetic regulation of biological nitrogen fixation // Nat. Rev. Microbiol.-2004.-2.-P. 621-631.

61. Lee S., Reth A., Meletzus D., Sevilla M., Kennedy C. Characterization of a major cluster of nif, fix, and associated genes in a sugarcane endophyte, Acetobacter diazotrophicus // J. Bacteriol.-2000.-182, N 24.- P. 7088-7091.

62. Yahyaoui F. E., Kuster H., Ben Amor B., Hohnjec N., Puhler A., Becker A., Gouzy J., Vernie T., Gough C., Niebel A., Godiard L., Gamas P. Expression profiling in Medicago truncatula identifies more than 750 genes differentially expressed during nodulation, including many potential regulators of the symbiotic program // Plant Physiol.2004.-136.-P. 3159-3176.

63. Gagnon H., Ibrahim R. K. Aldonic acids: a novel family of nod gene inducers of Mesorhizobium loti, Rhizobium lupini 
and Sinorhizobium meliloti // Mol. Plant-Microbe Interact.1998.-11.-P. 988-998.

64. Mabood F., Souleimanov A., Khan W., Smith D. Jasmonates induce Nod factor production by Bradyrhizobium japonicum // Plant Physiol. Biochem.-2006.-44.-P. 759-765.

65. Yuen J. P. Y., Cassini S. T., De Oliveira T. T., Nagem T. J., Stacey $G$. Xanthone induction of nod gene expression in Bradyrhizobium japonicum // Symbiosis.-1995.-19.-P. 131140.

66. D’Haeze $W$., Holsters M. Surface polysaccharides enable bacteria to evade plant immunity // Trends Microbiol.2004.-12.-P. 555-561.

67. Fujishige N. A., Kapadia N. N., De Hoff P. L., Hirsch A. M. Investigations of Rhizobium biofilm formation // FEMS Microbiol. Ecol.-2006.-56.-P. 195-206.

68. Laus M. C., Logman T. J., Lamers G. E., van Brusel A. A. N., Carlson R., Kijne J. $W$. A novel polar surface polysaccharide from Rhizobium leguminosarum binds host plant lectin // Mol. Microbiol.-2006.-59.-P. 1704-1713.

69. Rudiger H., Gabius H. J. Plant lectins: occurrence, biochemistry, functions and applications // Glycoconj. J.-2001.18.-P. 589-613.

70. Karpunina L. V., Smiyan M. S., Kosenko L. V. The effect of the carbohydrate components of pea roots on the enzymatic activity of the surface agglutinins of Rhizobium leguminosarum bv. viciae 252 // Microbiology.-2004.-73, N 4.P. 461-464.

71. Antonyuk L. P., Ignatov $V$. $V$. The role of wheat germ agglutinin in plant-bacteria interactions: a hypothesis and the evidence in its support // Russ. J. of Plant Physiol.-2001.-48, N 3.-P. 427-433.

72. Theunis M., Kobayashi H., Broughton W. J., Prinsen E. Flavonoids, NodD1, NodD2, and nod box NB15 modulate expression of the $\mathrm{y} 4 \mathrm{wEFG}$ locus that is required for indole-3-acetic acid synthesis in Rhizobium sp. strain NGR234 // Mol. Plant-Microbe Interact.-2004.-17.P. 1153-1161.

73. Kannenberg E., Perzl M., Hartner T. The occurrence of hopanoid lipids in Bradyrhizobium bacteria // FEMS Microbiol. Lett.-1995.-127.-P. 255-262.

74. Matiru V. N., Dakora F. D. Xylem transport and shoot accumulation of lumichrome, a newly recognized rhizobial signal, alters root respiration, stomatal conductance, leaf transpiration and photosynthetic rates in legumes and cereals // New Phytologist.-2005.-165.-P. 847-855.

75. Molecular bases of the relationships between associative microorganisms and plants / Ed. V. V. Ignatov.-M.: Nauka, 2005.-262 p.

76. Kravchenko L. V., Azarova T. S., Makarova N. M., Tikhonovich $I$. $A$. The effect of tryptophan present in plant root exudates on the phytostimulating activity of rhizobacteria // Microbiology.-2004.-73, N 2.-P. 195-198.

77. Penrose D. M., Glick B. R. Methods for isolating and characterizing ACC deaminase-containing plant growth-promoting rhizobacteria // Physiol. Plant.-2003.-118, N 1.-P. 13101372.

78. Kloepper J. W., Ryu Ch.-M., Zhang Sh. Induced systemic resistance and promotion of plant growth by Bacillus spp. // Phytopathology.-2004.-94, N 11.-P. 1259-1266.

79. Loon L. C. Plant responses to plant growth-promoting rhizobacteria // Eur. J. Plant Pathol.-2007.-119, N 3.-P. 243-254.

80. Jetiyanon K., Kloepper J. W. Mixtures of plant growth-promoting rhizobacteria for induction of systemic resistance against multiple plant diseases // Biol. Control.- 2002.-24, N 3.-P. 285-291.

81. Cartieaux F., Thibaud M.-C., Zimmerli L., Lessard S., Sarrobert C., David P., Gerbaud A., Robaglia C., Somerville S., Nussaume L. Transcriptome analysis of Arabidopsis colonized by a plant-growth promoting rhizobacterium reveals a general effect on disease resistance // Plant J.-2003.-36, N 2.-P. 177-188.

82. Whipps $J$. M. Microbial interactions and biocontrol in the rhizosphere // J. Exp. Bot.-2001.-52, Special issue.-P. 487511.

83. Mehnaz S., Weselowski B., Lazarovits G. Azospirillum canadense sp. nov., a nitrogen-fixing bacterium isolated from corn rhizosphere // Int. J. Syst. Evol. Microbiol.-2007.- 57.P. 620-624.

84. Zhu G. Y., Dobbelaere S., Vanderleyden J. Use of green fluorescent protein to visualized rice root colonization by $\mathrm{AzO}$ spirillum irakense and A. brasilense // Funct. Plant Biol.2002.-29.-P. 1279-1285.

85. Michiels K., Croes C. L., Vanderleyden J. Two different modes of attachment of Azospirillum brasilense $\mathrm{Sp} 7$ to wheat roots // J. Gen. Microbiol.-1991.-137.-P. 2241-2246.

86. Katzy E. I. Molecular-genetic aspects of formation at Azospirillum brasilense $\mathrm{O}$-specific polysaccharides, motor organells and extracells metabolite important for this bacteriaplant interactions: Thesis. E Dr. biol. sci.-M., 2002.-388 p.

87. Katzy E. I. Characterization of genes identified in the 120MDa plasmid of an Azospirillum brasilense Sp245 mutant defective in polar flagellation and swarming // Russ. J. of Genetics.-2002.-38, N 1.-P. 22-32.

88. Burdman S., Okon Y., Jurkevitch E. Surface characteristics of Azospirillum brasilense in relation to cell aggregation and attachment to plant roots // Crit. Rev. Microbiol.-2000.-26, N 2.-P. 91-110.

89. de Oliveira Pinheiro R., Boddey L. H., James E. K., Sprent J. I., Boddey R. M. Adsorption and anchoring of Azospirillum strains to roots of wheat seedlings // Plant and Soil.2002.-246, N 2.- P. 151-166.

90. Karpati E., Kiss P., Pony T., Fendrik I., De Zamaroczy M., Orosz L. Interaction of Azospirillum lipoferum with wheat germ agglutinin stimulates nitrogen fixation // J. Bacteriol.1999.-181, N 13.-P. 3949-3955.

91. Steenhoudt O., Vanderleyden J., Kefalogianni I., Aggelis G. Modelling growth and biochemical activities of Azospirillum spp. // Appl. Microbiol. Biotechnol.-2002.-58, N 3.-P. 352357.

92. Fedonenko Yu. P., Konnova O. N., Zatonsky G. V., Shashkov A. S., Konnova S. A., Zdorovenko E. L., Ignatov V. V., Knirel $Y u$. A. Structure of the O-polysaccharide of the lipopolysaccharide of Azospirillum irakense KBC1// Carbohydr. Res.-2004.-339, N 10.-P. 1813-1816.

93. Fedonenko Yu. P., Egorenkova I. V., Konnova S. A., Ignatov $V$. $V$. Involvement of the lipopolysaccharides of azospirilla in the interaction with wheat seedling roots // Microbiology.-2001.-70, N 3.-P. 384-390.

94. Fedonenko Yu. P., Zdorovenko E. L., Konnova S. A., Ignatov $V$. V., Shlyakhtin G. V. Comparison of the lipopolysaccharides and O-specific polysaccharides of Azospirillum brasilense Sp245 and its omegon-Km mutants KM018 and KM252 // Microbiology.-2004.-73, N 2.-P. 180-187.

95. Fedonenko Yu. P., Borisov I. V., Konnova O. N., Zdorovenko E. L., Katsy E. I., Konnova S. A., Ignatov V. V. Determination of the structure of the repeated unit of the Azospirillum 
brasilense SR75 O-specific polysaccharide and homology of the lps-loci in the plasmids of Azospirillum brasilense strains SR75 and Sp245 // Microbiology.-2005.-74, N 5.-P. 542558.

96. Antonyuk L. P., Fomina O. R., Ignatov $V$. V. Effect of wheat lectin on the metabolism of Azospirillum brasilense: induction of protein synthesis // Microbiology.-1997.-66, N 2.-P. 172-178.

97. Antonyuk L. P., Fomina O. R., Kalinina A. V., Semynov S. V., Nesmeyanova $M$. A., Ignatov $V$. $V$. Wheat lectin possibly serves as a signal molecule in Azospirillum-wheat association // Azospirillum VI and related microorganisms: Genetics, physiology, ecology / Eds I. Fendrik et al.-Berlin: Springer (NATO ASI Ser.; V. G37), 1995.-P. 319-324.

98. Wasson A. P., Pellerone F. I., Mathesius U. Silencing the flavonoid pathway in Medicago truncatula inhibits root nodule formation and prevents auxin transport regulation by rhizobia // Plant Cell.-2006.-18.-P. 1617-1629.

99. Spaepen S., Vanderleyden J., Remans R. Indole-3-acetic acid in microbial and microorganism-plant signaling // FEMS Microbiol. Rev.-2007.-31, N 4.-P. 425-448.

100. Costacurta A., Vanderleyden J. Synthesis of phytohormones by plant-associated bacteria // Crit. Rev. Microbiol.-1995.21, N 1.-P. 1-18.

101. Van de Broek A., Gysegom P., Ona O., Hendrickx N., Prinsen E., Van Impe J., Vanderleyden J. Transcriptional analysis of the Azospirillum brasilense indole-3-pyruvate decarboxylase gene and identification of a cis-acting sequence involved in auxin responsive expression // Mol. Plant-Microbe Interact.-2005.-18.-P. 311-323.

102. Malhotra M., Srivastava S. An ipgC gene knock-out of Azospirillum brasilense strain $\mathrm{SM}$ and its implications on indole-3-acetic acid biosynthesis and plant growth promotion // Antonie van Leeuwenhoek.-2008.-93, N 4.-P. 425-433.

103. Somers E., Ptacek D., Gysegom P., Srinivasan M., Vanderleyden J. Azospirillum brasilense produces the auxin-like phenylacetic acid by using the key enzyme for indole3-acetic acid biosynthesis // Appl. Environ. Microbiol.2005.-71.-P. 1803-1810.

104. Spaepen S., Vanderleyden J., Remans R. Indole-3-acetic acid in microbial and microorganism-plant signaling // FEMS Microbiol. Rev.-2007.-31.-P. 425-448.

105. Sergeeva E., HirkalaD. L. M., Nelson L. M. Production of indole-3-acetic acid, aromatic amino acid aminotransferase activities and plant growth promotion by Pantoea agglomerans rhizosphere isolates // Plant and Soil.-2007.297, N 1-2.-P. 1-13.

106. Cassan F., Bottini R., Schneider G., Piccoli P. Azospirillum brasilense and Azospirillum lipoferum hydrolyze conjugates of GA20 and metabolize the resultant aglycones to $\mathrm{GA}_{1}$ in seedlings of rice dwarf mutants // Plant Physiol.-2001.125.-P. 2053-2058.

107. Oger P. M., Mansouri H., Nesme X., Dessaux Y. Engineering root exudation of Lotus toward the production of two novel carbon compounds leads to the selection of distinct microbial populations in the rhizoshere // Microbiol. Ecol.-2004.-47, N 1.-P. 96-103. 